${ }^{4}$ Goel, K M, and Shanks, R A, Annals of the Rheumatic Diseases, 1974, 33, 25.

${ }^{5}$ Rynes, R I, et al, Arthritis and Rheumatism, 1976, 19, 161.

${ }^{6}$ Bianco, N E, et al, Arthritis and Rheumatism, 1971, 14, 685.

${ }^{7}$ Moore, T, Dorner, R W, and Zuckner, J, Annals of the Rheumatic Diseases, 1974, 33, 255.

${ }^{8}$ Ziff, M, Federation Proceedings, 1973, 32, 131.

9 Sullivan, D B, Cassidy, J T, and Petty, R E, Arthritis and Rheumatism, $1975,18,251$.

${ }^{10}$ Rahal, J J, Millian, S J, and Noriega, E R, Fournal of the American Medical Association, 1976, 235, 2496.

11 Linnemann, C C, Jr, et al, Annals of the Rheumatic Diseases, 1975, 34, 354.

12 Ogra, P L, et al, Lancet, 1975, 1, 1157.

${ }^{13}$ Fabricant, M S, Chandor, S B, and Friou, G J, fournal of the American Medical Association, 1973, 225, 273.

14 Sills, E M, Medical Clinics of North America, 1975, 59, 1497.

15 Bywaters, E G L, Annals of the Rheumatic Diseases, 1971, 30, 121.

${ }_{16}$ Smith, J W, and Sanford, J P, Annals of Internal Medicine, 1967, 67, 651.

17 Ansell, B M, and Bywaters, E G L, Bulletin on Rheumatic Diseases, 1959, $\mathbf{9}, 189$.

18 Brewer, E J, et al, Bulletin on Rheumatic Diseases, 1973, 23, 712.

19 Cassidy, J J, et al, Pediatrics, 1974, 54, 239.

${ }^{20}$ Høyeraal, H M, and Mellbye, O J, Annals of the Rheumatic Diseases, $1974,33,248$.

${ }^{21}$ Schnitzer, T, Howard, A, and Ansell, B M, in preparation.

22 Medical Research Council, Multiple Sclerosis Research. London, HMSO, 1976.

${ }^{23}$ Høyeraal, H M, Frøland, S S, and Wisløff, F, Scandinavian fournal of Immunology, 1975, 4, 801.

24 Jennings, J, Annals of the Rheumatic Diseases, 1975, 34, 196.

25 Edmonds, J, et al, Annals of the Rheumatic Diseases, 1974, 33, 576.

${ }^{26}$ Edmonds, J, et al, Annals of the Rheumatic Diseases, 1974, 33, 289.

27 Buc, M, Nyulassy, S, and Stefanovic, J, Tissue Antigens, 1974, 4, 395.

${ }^{28}$ Rachelefsky, G S, et al, New England fournal of Medicine, 1974, 290, 892.

${ }^{29}$ Nissilä, M, Elomaa, L, and Tiilikainen, A, New England fournal of Medicine, 1975, 292, 430.

${ }^{30}$ Gibson, D J, et al, New England fournal of Medicine, 1975, 293, 638.

31 Ansell, B M, Bywaters, E G L, and Lawrence, J S, Annals of the Rheumatic Diseases, 1962, 21, 243.

32 Brewerton, D A, ed, Annals of the Rheumatic Diseases, 1975, 34, suppl 1.

${ }^{33}$ Doherty, P C, and Zinkernagel, R M, Lancet, 1975, 1, 1406.

${ }^{34}$ Phillips, P E, Journal of Experimental Medicine, 1971, 134, 3135.

${ }^{35}$ Middleton, P J, and Highton, T C, Annals of the Rheumatic Diseases, 1975, 34, 369.

${ }^{36}$ Hamerman, D, Annals of the New York Academy of Sciences, 1975, 256, 25.

${ }^{37}$ Schumacher, H R, and Kitridou, R C, Arthritis and Rheumatism, 1972, 15, 465 .

\section{Dealing with alcoholism}

Alcoholism provides a common ground for physicians, psychiatrists, accident surgeons, physiologists, and geneticists. Together with other experts representatives of these disciplines met last month at the Institute of Psychiatry in London to discuss their mutual interest. Despite the intense specialisation which each group is bringing to bear on its own facet of the problem, the impression left by the meeting was that these preoccupations were bringing the various workers closer together, rather than the opposite.

Recent studies on mice had confirmed that acetaldehyde metabolism may hold the key to dependence and possibly to individual susceptibility to alcohol intoxication. Factors such as age and sex as well as the genetic strain seemed to be important. This added point to a full review of genetic factors in human alcoholism, though the conclusion seemed to weigh against heredity's being a major determinant in an unclearly defined syndrome with social as well as medical features.

A discussion of the medical markers of alcoholism (heavily weighted on reports of liver cirrhosis) suggested that these may be somewhat less reliable than is usually assumed. This lack of objective definition when it might most have been expected paved the way for a consideration of the role of habit, as seen by a psychologist, in controlling behaviour. Together with an acceptance of social and cultural pressures in the development of drinking habits early in life, it set the scene for a vigorous discussion on liquor licensing laws and the recent proposals ${ }^{12}$ to amend them. Dr Wolfgang Schmidt presented epidemiological evidence gathered at the Alcohol Research Foundation in Toronto which emphasised the association between per caput consumption of alcohol and harmful drinking, and the direct relation of both to availability of alcohol. This matter was raised in discussion during a session of which Dr Christopher Clayson was chairman. Increased availability by extension of licensing hours, he argued, might not necessarily raise consumption nor increase drunkenness if it relieved "the pressure to drink," which Dr Clayson saw as such an undesirable feature of life in Scotland.

Another controversial issue concerned the results of treatment, with particular reference to the analysis ${ }^{3}$ of largescale statistics concerning men attending community treatment centres in the United States. This confirmed reports that remission (as evidenced by a return to normal drinking or reduced consumption attended by improved social relations) is far more frequent than total abstinence, the usual goal of treatment. Methods of working towards such remission were discussed, as well as the underlying psychological theories of learning which gave scientific ground to a re-educative approach to treatment. Learning theory contrasts sharply with the current preoccupation with psychodynamically orientated group work so evident in most alcohol treatment units in Britain and elsewhere. Nevertheless, the re-education of alcoholics to a different life style is now being tried in some practices. Another heartening trend is collaboration between physicians and psychiatrists, described by some speakers, even if it is only beginning to emerge here.

Discussion of changes in the approach to treatment naturally led to a debate about the pattern of services needed in Britain if the rising tide of alcoholism is to be stemmed and the public is to be made more aware of the facts about the disease. Who is to compose the teams and who is to lead them ? One point that should not need arguing is that whoever does head the team should have the relevant knowledge not only from his own field but also from that of his colleagues.

1 The Erroll Report: Report of the Departmental Committee on Liquor Licensing, Cmnd 5154. London, HMSO, 1972.

2 The Clayson Report: Report of the Departmental Committee on Scottish Licensing Law, Cmnd 5354. Edinburgh, HMSO, 1973.

${ }^{3}$ Armor, D J, Polich, J M, and Stambul, H B, Alcoholism and Treatment, pp 1-216. Santa Monica, Rand Corporation, 1976. 